\title{
First Boston Meeting Breaks All Records
}

$T^{n}$ 1998 APSA Annual Meeting attracted 6,633 political scientists, exhibitors, and members of the press to Boston, a first-time host for the 94-year-old convention. Six thousand one hundred forty-nine registered political scientists (231 more than 1997) attended over 720 panel sessions at the Sheraton Boston, Marriott Copley Place, and the Westin Copley Plaza.

The 1998 program, organized by 46 division chairs led by Program Chair Virginia Sapiro, University of Wisconsin, Madison, was organized around the theme "Community, Communities, and Politics." Over 100 panels were designated as "theme sessions," and the two highest attendance figures were recorded for "Democracy in Changing Civil Societies," chaired by Theda Skocpol, Harvard University (380 attendees), and "Are Civil Society and Communitarianism Really Non-Partisan?" chaired by Benjamin Barber, Rutgers University (248 attendees). The Related Group panel hosted by The New York Times, "The Prosecutor and the President" boasted the third largest attendance. It drew 218 during the Saturday evening session.

Poster sessions, now an established form of academic exchange at the APSA meeting, included over 350 presenters in five sessions: Comparative Politics and International Relations (2 sessions), American Politics (2 sessions), Political Methodology, Political Theory, and Teaching and Learning in Political Science. Poster presentations by research support institutions included, among many others, representatives from the U.S. Institute of Peace, U.S. Department of Education, Consortium of Social Science Associations, The Aspen Institute, and the National Science Foundation.

A lively Awards Ceremony was hosted by Virginia Sapiro on Thursday evening, followed by a wellattended Presidential Address, "Po-

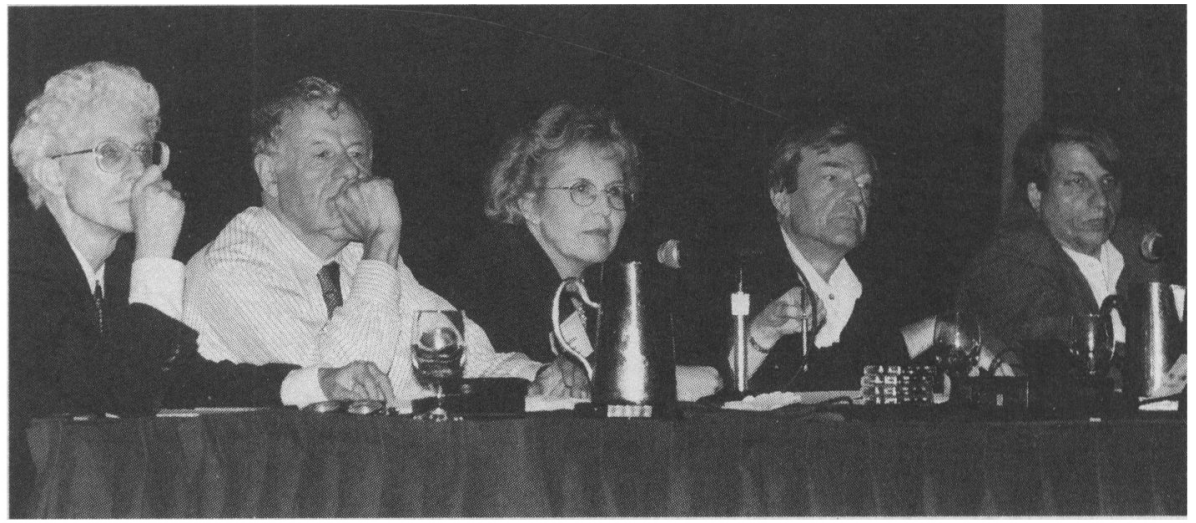

Members of the theme panel, "Are Civil Society and Communitariaism Really Non-Partisan? A Roundtable Debate," await a question from one of the 248 session attendees. Participants include [from left]: William A. Galston, University of Maryland; Amitai Etzioni, George Washington University; Jean Bethke Elshtain, University of Chicago; Michael Sandel, Harvard University; and Benjamin R. Barber, Rutgers University.

litical Responses to Pain and Loss," by M. Kent Jennings, University of California, Santa Barbara.

Three special guest lectures highlighted the Boston meeting, beginning on Thursday with the annual Pi Sigma Alpha Lecture, given this year by Representative Christopher Shays (R-CT). Shays gave an address titled "Campaign Finance Reform Lives." On Friday, two APSA award winners presented their lectures. W. Lance Bennett, University of Washington and the recipient of the Ithiel de Sola Pool Award, described "The UnCivic Culture: Communication, Identity, and the Rise of Lifestyle Politics," and Louis C. Gawthrop, University of Baltimore and the John Gaus Award winner, spoke on "The Human Side of Public Administration." Both the Pool and Gaus lectures appear in this issue of $P S$.

This year's Hyde Park sessions, designed for informal and controversial discussion, were held outside the poster sessions in the Sheraton Boston. The three timely topics were "The Independent Counsel: Should We Change the Game or the Players," "The Politics of GovernmentFunded Research," and "Do the New Media Improve Political Communication?"
The 1998 Department Chairs' Conference and Professional Day on Wednesday, now in its sixth year, featured over 20 short courses, workshops, and sessions. Many of the short courses, hosted by APSA Organized Sections, were held at a variety of locations throughout the Boston area. The Chairs' Conference featured sessions on "Political Science Undergraduate Enrollments and Majors, An Update" and "Assessing Political Science Programs and Faculty." Short courses continue to be popular with graduate students and academics eager to pursue a variety of topics in-depth during sessions that last three to eight hours. The Organized Section on Political Methodology launched an experiment by videotaping two of its sessions for distribution and later use in classrooms.

The APSA will not return to Boston until 2002, when we again anticipate sunny skies, upscale shopping, and the Gourmet Bean. In the meantime, preparations are well underway for the 95th Annual Meeting, September 2-5, in Atlanta, Georgia. For details on the Atlanta meeting, be sure to visit APSANet (www.apsanet.org) and look for more information in future issues of $P S$. 


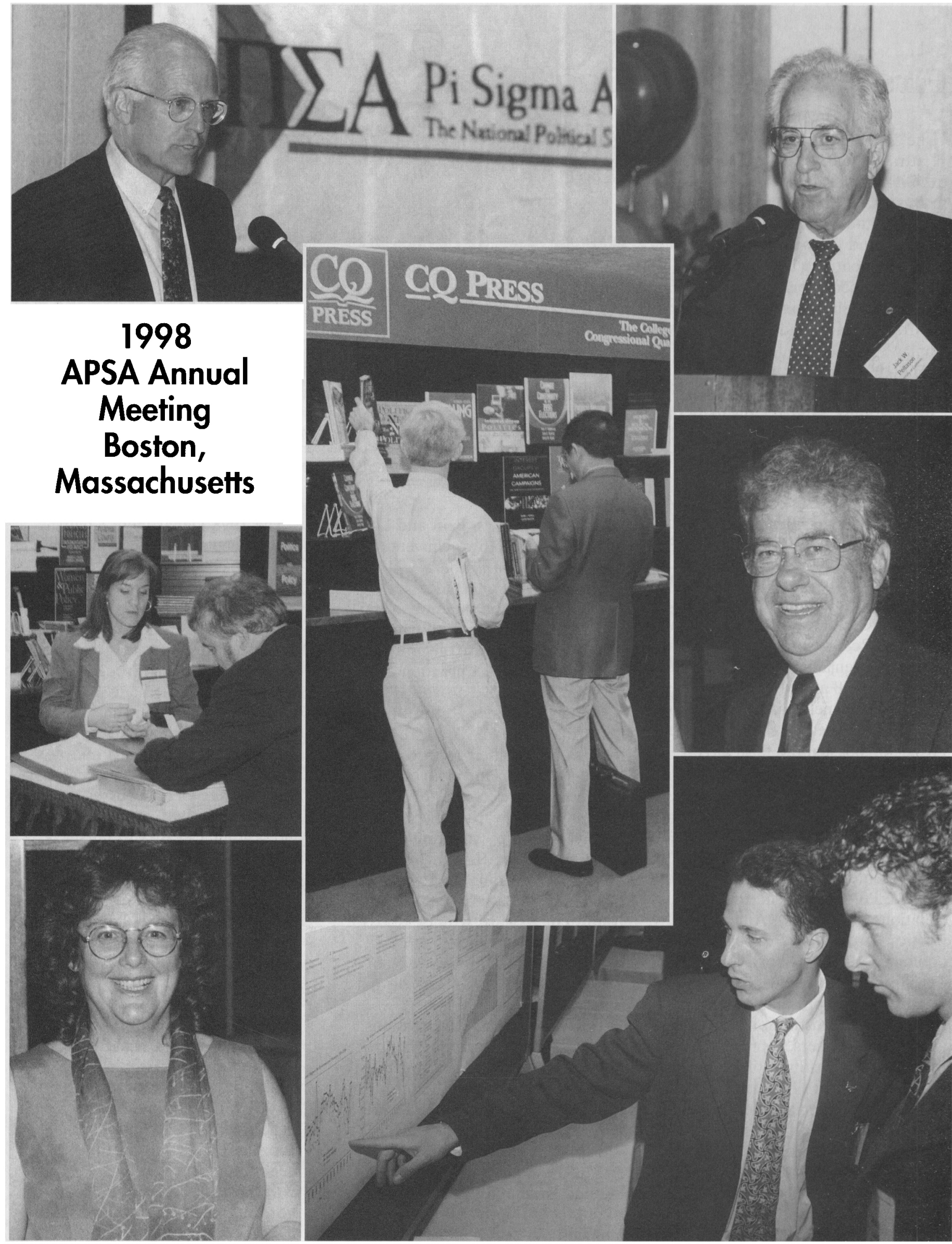

